\title{
Representasi Budaya Konsumen dalam Iklan Djarum Super Edisi Paolo
}

\section{Maldini}

\author{
Azhar Maulana Akbar \\ Program Studi Ilmu Komunikasi, Universitas Muhammadiyah Yogyakarta, Indonesia \\ azhar.maulana.isip19@mail.umy.ac.id \\ Muhammad Rizki Tamimi \\ Program Studi Ilmu Komunikasi, Universitas Muhammadiyah Yogyakarta, Indonesia \\ rizki.tamimi.isip19@mail.umy.ac.id \\ Yoga Rachmat Febrianto \\ Program Studi Ilmu Komunikasi, Universitas Muhammadiyah Yogyakarta, Indonesia \\ yoga.rachmat.isip19@mail.umy.ac.id \\ Diserahkan: 12 Juni 2021; Direvisi: 15 Juli 2021; Diterima: 24 Juli 2021
}

\begin{abstract}
Djarum Super is a popular cigarette brand in Indonesia which is produced by PT Djarum and it is well known in Indonesia and Nigeria. This product is made through various media played by several famous artists and even a very famous football player, namely Paolo Maldini. The purpose of this research is for understanding Paolo Maldini edition of Djarum Super advertisement by using semiotic method. In Paolo Maldini;s Djaurm Super Edtion commercial, there is a scene showing several men playing basketball by wearing branded shoes. The myth of this advertisement is that being a famous sportsman is synonymous by wearing fashion that has a well-known brand. The existence of sports cannot be separated from consumer culture, namely the use of popular brands, such as Nike and Adidas. This myth shows the existence of consumer culture in advertising.

Keywords: Consumer Culture; Djarum Super; Advertisement; Paolo Maldini; Semiotics
\end{abstract}

\begin{abstract}
Abstrak
Djarum Super merupakan sebuah merek rokok ternama di Indonesia yang diproduksi oleh PT Djarum dan terkenal di Indonesia maupun Nigeria. Produk ini dipromosikan melalui berbagai macam media yang diperankan oleh beberapa artis terkenal bahkan sampai pemain bola yang sangat terkenal yaitu Paolo Maldini. Penelitian ini bertujuan untuk mengkaji iklan Djarum Super Edisi Paolo Maldini dengan menggunakan metode semiotika. Dalam iklan Djarum Super Edisi Paolo Maldini terdapat adegan yang memperlihatkan beberapa pria yang sedang bermain basket dengan sepatu bermerek. Mitos dari iklan ini adalah bahwa menjadi olahragawan terkenal identik dengan pemakaian fashion yang memiliki merek terkenal. Keberadaan olahraga tidak lepas dari budaya konsumen, yaitu penggunaan merek ternama, seperti Nike dan Adidas. Mitos ini menunjukan adanya budaya konsumen dalam iklan.

Kata Kunci: Budaya Konsumen; Djarum Super; Iklan; Paolo Maldini; Semiotika
\end{abstract}




\section{PENDAHULUAN}

Iklan merupakan bentuk komunikasi yang biasa digunakan untuk keperluan penyampain suatu informasi atau pesan tentang produk, layanan, maupun informasi. Gaya hidup masyarakat modern seperti sekarang tidak jauh-jauh dengan media massa yang memiliki sifat mengikuti perkembangan zaman, ini terjadi karena media massa saat ini telah menjadi alat atau media untuk penyampaian pesan kepada khalayak ramai. Hampir semua lapisan masyarakat memanfaatkan televisi sebagai media untuk mendapatkan informasi. Dari banyaknya program tanyangan pada televisi yang terdapat pada televisi, iklan menjadi salah satu tayangan yang lumayan banyak ditonton audiens.

Dunia periklanan semakin maju seiring dengan pertumbuhan era teknologi yang cukup pesat, sebelum munculnya smartphonedan televisi, informasi akan suatu produk atau jasa hanya disiarkan melalui koran, poster dan radio. Setelah munculnya smartphone, iklan tidak hanya ditampilkan lewat media televisi dan radio semata. Sekarang iklan tersebar luas di sosial media uang dengan mudah diakses lewat smartphone.

Pada umunya masyarakat cukup banyak meluangkan waktu untuk menonton televisi, sebagai referensi berita, hiburan, serta sarana pendidikan. Calon konsumen lebih "yakin" terhadap perusahaan yang mengiklankan produk merekapada siaran televisi dari pada yang tidak mengiklankan sama sekali. Ini merupakangambaran bonafiditas pengiklan. Selain itu, penayangan iklan pada televisi juga masih berhubungan dengan aspek moralitas masyarakat dan penyemuan persepsi publik. Produk yang dijualpada iklan di televisi sebagian memuat unsur inspiratif, yang secara persuasif memberikan pengaruh kepada masyarakat untuk membeli produk tersebut. Terdapat juga iklan yang mempunyai konsep berbeda dan unik. Penyajian iklan pada masa sekarang juga memiliki kemampuan daya tarik yang lebih kuat karena iklan sudah ditampilkan dalam bentuk audio serta visual. Pada iklan elektronik yang ditampilkan media televisi, memiliki beragam varian iklan baik berupa siaran tentang edukasi hingga iklan-iklan yang mengandung unsur komersil. Faktanya iklan-iklan yang ditampilkan pada tayangan televisi terbukti dapat berkontribusi untuk mempengaruhi keputusan dalam pemilihan produk.

Adapun pada iklan Djarum Super Edisi Paolo Maldini terdapat adegan yang memperlihatkan beberapa pria yang sedang bermain basket dengan sepatu bermerek. Pada iklan tersebut juga diperlihatkan ada seorang pria yang mampu memasukan bola ke dalam ring basket tanpa melihat ke arah ring, yang mana pria tersebut juga menggunakan sepatu bermerek. Iklan Djarum Super ini juga secara tidak langsung memunculkan realitas bahwa dengan memakai sepatu bermerek dapat memberikan dampak pada permainan basket. Selain dikenakan Paolo Maldini, sepatu bermerek pada iklan tersebut juga digunakan oleh legenda basket Perancis, Tony Parker yang mana ini juga secara tidak langsung menambah realitas baru bahwa pemain hebat memakai sepatu bermerek.

Dari penjelasan di atas, dapat disimpulkan bahwa tubuh perempuan dalam budaya konsumen Indonesia seperti tercermin dalam Miss Jinjing Belanja Sampai Mati (2008) merupakan situs pertarungan ideologi, yaitu ideologi kapitalisme, konsumerisme dan ideologi patriarki. Ketiga ideologi ini saling mengukuhkan satu sama lain dan tidak ada satu ideologi pun yang runtuh, sehingga pada akhirnya terjadi koherensi antar masing-masing ideologi. Implikasi praktis dari penelitian ini adalah perempuan urban dapat menjadi lebih kritis terhadap kekuasaan (ideologi-idelogi) yang mengungkung tubuhnya melalui praktek konsumsi. Mereka tidak perlu mengonstruksi tubuh sesuai tuntutan kapitalis. Menjadi diri sendiri dan berpuas diri dengan tubuh yang dimiliki. Penelitian ini tidak berhenti pada analisis teks saja, tetapi masih banyak hal yang bisa diteliti. Keterlibatan peneliti secara langsung mengamati dan mengikuti perilaku konsumsi perempuan urban Jakarta yang tergabung dalam komunitas tersebut sangat penting untuk memberikan gambaran yang lebih utuh dan jelas mengenai fenomena budaya perempuan urban Jakarta dalam budaya konsumen Indonesia. 
Pengambilan keputusan pembelian konsumen bukan proses tunggal. Topologi keputusan pembelian konsumen didasarkan pada 2 dimensi yaitu derajat pengambilan keputusan dan derajat keterlibatan dalam pembelian. Ada penelitian yang menemukan bahwa orang yang lebih terlibat, memberikan perhatian lebih pada iklan dan memperoses informasi produk dalam iklan lebih ekstensif. Peneliti lainnya membedakan keterlibatan menjadi dua tipe yaitu keterlibatan ego dan keterlibatan pembelian. Salah satu peneliti lainnya memberikan kerangka pemikiran komprehensif akan keterlibatan menurut tiga aliran penelitian dalam perilaku konsumen (Rosida, 2018)

Penelitian terdahulu menyatakan bahwa pembeli sepatu bermerek Nike didominasi oleh kaum pria, dimana hal ini sejalan dengan penelitian ini yang target utama dari iklan Djarum Super yang menyasar kaum pria alih-alih kaum perempuan (Hanum \& Hidayat, 2017). Penelitiannya menyimpulkan bahwa terdapat empat faktor yang menyebabkan orang memilih produk Nike diantaranya, pribadi, psikologis, budaya, dan sosial. Pada indikator faktor kebudayaan konsumen dalam hal pengambilan keputusan membeli sepatu merek Nike yaitu karena berbagai alasan antaralain, kebiasaan, gaya hidup, keinginann pribadi, nilai, kelas sosial dimata masyarakat dan kepercayaan. Pada indikator faktor kebudayaan konsumen dalam pengngambilan keputusan membeli sepatu merek Nike yaitu karena pravelensi, gaya hidup, selera pribadi, nilai/norma-norma. Adapun penelitian selanjutnya mengatakan bahwa pengambilan keputusan konsumen dalam hal pembelian bukan merupakan sebuah proses tunggal ( Siringoringo, 2004). Topologi pengambilan keputusan konsumen berdasarkan dua hal yaitu derajat pengambilan keputusan serta derajat keterlibatan pada proses pembelian.

\section{KAJIAN PUSTAKA}

\section{REPRESENTASI}

Representasi ialah produksi makna konsep pada pikiran kita lewat bahasa, itu merupakan relasi antara konsep dan bahasa yang kemungkinan kita untuk merujuk ke dunia sungguhan mengenai objek, orang atau peristiwa, atau bahkan dunia imajiner benda fiksi, orang, serta peristiwa. Representasi juga menjadi bagian vital dari proses dimana makna diproduksi dan terjadi pertukaran antara anggota budaya. Hal ini melibatkan penggunaan bahasa, tanda-tanda, serta visual yang mewakili atau mewakili sesuatu. Selain itu representasi juga berarti mengaplikasikan bahasa untuk menyuarakan sesuatu makna tentang, atau untuk mewakili dunia secara bermakna kepada orang lain (Hall, 1997)

Secara umum, teori representasi kelompok dengan sub kelompok invarian, di mana sub kelompok invarian adalah terjemahan tiga dimensi kelompok. Teori tambahan akan memungkinkan kita untuk mengisi kekosongan file bab terakhir, terutama untuk menunjukkan bahwa skema yang diuraikan untuk mendapatkan repetisi kelompok luar angkasa sebenarnya menghasilkan semuanya, tidak terlalu sedikit atau pun yang palsu yang setara dengan yang lain, tetapi juga untuk menunjukkan bagaimana mendapatkan dalam bentuk matriks yang tepat representasi lengkap dari representasi kecil yang ditabulasikan dari kelompok-kelompok kecil. Kebetulan teori tambahan ini memungkinkan kita untuk berdiskusi lebih lanjut dengan lebih mudah tempat menarik dalam teori benda padat, seperti realitas repetisi dan bagian dalamnya produk langsung satu sama lain. Realitas itu penting karena kegunaannya dalam mempelajari degenerasi partikel individu atau keadaan kuasi-partikel dalam kristal sebagai hasil dari simetri pembalikan waktu (Bradley \& Cracknell, 2009)

\section{BUDAYA KONSUMEN}

Budaya Konsumen sudah menetapkan diri pada identitas barupolitik dimana bisnis itu sendiri memiliki peran dalam membentuk identitas yang kondusif untuk jual beli. Identitas dalam hal ini menjadi gambaran dari "gaya hidup" yangerat serta terkait atas merek komersial dan produk label mereka, dengan sikap dan perilaku terkaittempat kita berbelanja, cara kita membeli, serta apa yang kita makan, pakai,dan 
konsumsi. Karakter ini pada masanyaberhubungan dengan pendapatan, kelas, dan otoritas ekonomi lain yang tampaknya mengizinkan opsi, tetapi kenyataannya sebagian besarditerminologikan oleh demografi, sosioekonomi dandiluar kendali konsumen individu. Gaya hidup bermerekbukan hanya terdapat pada lapisanpermukaan yang dalam pada identitas tetapi harus sampai taraf tertentu, sampai menjadi penggantiidentitasbentuk karakter yang diperoleh serta memilikipotensi untuk turun ke inti. Merekamencantumkanidentitas etnis serta budaya tradisional dan meliputi aspek individualitas sukarela yang kita pilih sendiri (Berger, 2010).

Aspek vital dari pengaruh budaya konsumen atas individu adalah terkait dengan identitas paradigma yang diilustrasikan dan diistimewakan dalam media masa serta periklanan. Model media dan selebriti yang diidealkan, sangat mepresentasikan dengan perwujudan serta bentuk tubuh yang ditingkatkan secara digital, tidak hanya mengiklankan produk, mereka juga turut mengkomunikasikan arahan gaya hidup serta personalitas kepada konsumen, memberikan cita-cita budaya keindahan, kesuksesan, dan kegembiraan (Dittmar, 2007).

\section{IKLAN}

Periklanan adalah pusat penciptaan dan pemeliharaan makna yang lebih luas. Merek seperti Marlboro, Mercedes-Benz, Gucci, Prada dan Rolls-Royce juga memiliki arti penting yang kuat bagi non-konsumen untuk konsumen. Bagi banyak konsumen barang bermerek membawa janji kualitas dan nilai. Namun secara simbolis berarti merek tersebut mungkin memiliki teman, kenalan dan orang asing tidak bisa didiskon sebagai faktor daya tariknya. Misalnya, item sederhana dari pakaian seperti kemeja akan laku dalam jumlah yang jauh lebih banyak jika memang demikian dihiasi dengan logo yang memberikan makna simbolis di atasnya barang. Mengenakan kemeja bermerek Tommy Hilfiger dikatakan branding prestige pada pemakainya karena nilai-nilai kemakmuran dan hak istimewa sosial yang diwakili oleh merek (Hackley, 2014)

Iklan juga dapat memengaruhi karyawan. Pada tahun 1997, Co-op Food Retail Stores di United Kingdom adalah salah satu dari kelompok koperasi yang menyusut (jumlah koperasi telah turun 90 persen dari tahun 1960 hingga 1996). Itu menderita penjualan yang menurun dan moral staf yang rendah. Akibatnya, perusahaan memutuskan untuk menekankan manfaatnya (kenyamanan, kejujuran, dan cara yang layak untuk menjalankan bisnis) dalam usahanya. Kampanye: "Bisnis dengan nilai-nilai keluarga hari ini." Tujuan kampanye tidak hanya untuk meningkatkan penjualan tetapi juga untuk mengurangi pergantian karyawan. Karyawan survei menunjukkan peningkatan, dengan komentar seperti "Itu [kampanye] kamu merasa sedikit lebih bangga bekerja untuk mereka." Pergantian karyawan turun sekitar seperempat. Kampanye tersebut memenangkan Penghargaan Efektivitas Periklanan (Armstrong, 2010)

\section{METODE PENELITIAN}

Sebagaimana yang sudah dijabarkanpada pendahuluan, penelitian ini mengkaji tentang iklan Djarum Super Edisi Paolo Maldini. Untuk memperoleh jawaban dari rumusan masalah pada penelitian ini menggunakan metode semiotika. Semiotika merupakan studi perihal produksi sosial makna dari sistem tanda. Studi semiotika ini diperkenalkan oleh cendekiawan bahasa Swiss, Ferdinand de Saussure. Semiotika merupakan ilmu yang menekuni kehidupan tanda-tanda dimasyarakat, pada sebuah buku yang terbit pada tahun 1916. Gagasannya tersebut dikembangkan oleh pemikir strukturalis Prancis bernama Roland Barthes, yang kemudian melazimkanserta memperlapang semiotika pada tahun 1960-an.

Saussure memaparkan semiotika seperti ilmu yang membahas tentang tanda sebagai komponen dari kehidupan sosial. Oleh Saussure, semiotika kelak dieksplanasi sebagai koneksi tripartit yakni tanda (sign) yang merupakan aliansi dari penanda (signifier) dan petanda (signified) (Hartley, 2003). 
Semiotika selaku upaya intelektual berusaha untuk membukakanserta menjabarkan sejauh mana substansi dihasilkan atas hubungan struktural yang terdapat dalam sistem simbol apa pun, serta bukan dari kenyataan eksternal yang terlihat begitu wajar untuk digambarkan. Karena ia berkomitmen pada pandangankorelasi sistematis yang berpraktekpada struktur abstrak (yaitu, struktur yang tidak dapat diamati secara langsung, seperti bahasa), semiotika mempunyai kecenderungan menuju arah abstraksi, formalisme, sertatidak mengindahkan prinsip historis. Namun, karena ia sama-sama berkomitmen atas produksi makna selaku sosial (bahasa tidak dapat ditemukan oleh individu), semiotika senantiasa berusaha untuk menghubungkan produksi makna atas jenis produksi sosial lain bersama dengan relasi sosial (Hartley, 2003).

Jadi semiotika awalnya berfokus pada tulisan, karena ia dispesifikanguna menganalisis bagaimana sistem makna melahirkan makna melalui teks. Akan tetapi seiring perkembangannya, keterkaitan yang lebih besar telah diberikan oleh peran pembaca saat merealisasikan atau menciptakan makna dari sumber tekstual melalui cara yang interaktif. Jadi semiotika diawali dengan menonjolkan bagaimana tulisan terstruktur pengerjaan ulang tanda, kode, dan seterusnya dari sistem tanda khusus mereka, serta bagaimana struktur ini menciptakankepercayaan/mitos, implikasi, dan sebagainya (Hartley, 2003).

Dengan demikian, semiotika berotasimengenai studi tentang tanda pada teks. Tanda (sign) terdiri dari dua faktor, yaitu penanda (signifiant), serta petanda (signified). Penanda bisa dimengerti sepertibentuk/wujud fisik. Penanda juga bisa berupa suara, gambar, huruf, visual dan lain-lain. Sedangkan petanda merupakanpersepsi atau arti dari apa yang ditandai. Hubungan antara keduanya bersifat "diada-adakan" (arbitrary), yang bermakna tidak ada hubungan yang sifatnya alamiah antara penanda dan petanda.

Saussure mengemukakan bahwa setiap tanda (atau kata) pada sistem bahasa melekat erat dengan sistem secara menyeluruh. Sebuah kata 'konten benar-benar ditetapkan hanya dengan persetujuan dari segala sesuatu yang ada di sekitarnya'. Untuk mevisualkan hal ini, Saussure memproduksidivergensi antara bahasa (keseluruhan sistem atau struktur) serta pembebasan bersyarat (ucapan khusus dalam sistem ini) mengenai bahasa tertentu. Sebuah tuturan (parole) hanya dapat menandakan makna secara praktis pada hubungannya atas seluruh sistem bahasa (bahasa) (Laughey, 2007). Langue dan parole merupakan pemikiran Saussure yang memperlihatkan bahwa tanda terkait dengan struktur. Langue adalah abstraksi serta artikulasi bahasa dalam tingkat sosial budaya, sedangkan parole ialah ekspresi bahasa pada tingkat personal. Supaya lebih gampang memahaminya, langue bisa jugadisebut sebagai sistem bahasa yang berjalan, sedangkan parole ialah bagaimana individu berbahasa pada sistem tersebut. Dengan demikian, maka parole terkait dengan langue. Permainan catur dapat menjadi sebuah contoh yang bisa memperterang mengenai langue dan parole.

Setiap aktivitas individu pada catur dipilih dari semua aturan gerakan catur yang memungkinkan. Jadi kita bisa mengatakanaturan catur yang boleh jadi bergerak sebagai bahasa catur. Setiap tindakan individu pada permainan catur akan dibebaskan bersyarat, pemilihan tindakan dari semua rangkaian gerakan yang memungkinkan pada bahasa catur (Laughey, 2007). Inilah yang menjadikan semiotika erat dengan strukturalisme.

Gagasan Saussure diteruskan oleh mitos Roland Barthes dengan memperluas teori Saussure mengenai sistem bahasa dengan menerapkannya atas sistem di mana masyarakat serta budaya meluaskan 'mitos'. Masyarakat serta budaya, misalnya bahasa, memiliki anggapan terstruktur oleh sistem 'keseluruhan' yang menentukan elemen masing-masing. Tentu saja, bahasa selakuaturan juga menjadi fondasi bagaimana masyarakat atau kultur bertahan. Tetapi Barthes menerangkan bahwa makna ilmu bahasa murni diganti secara subversif oleh manifestasi sosial dan budaya (Laughey, 2007). Fundamen yang dikemukakan oleh Barthes ialahsaling terkaitmengenai mitos. Mitos yang diimplikasikan oleh Barthes ialah pemaknaan 
secara konotatif pada teks budaya populer.Pemikiran Barthes adalah lanjutan dari pengandaian Saussure tentang relasi bahasa serta makna atau antara penanda dan petanda. Semiotika yang diciptakan Saussure lebih berkecenderungan untuk mengatakan bahwa makna seperti apa yang disignifikasikan oleh tanda.

Gagasan berikut dikembangkan oleh Barthes dengan mengatakan bahwa sejatinya kedapatan makna lain yang bahkan bermain dalamtingkat penandaan sekunder/kedua (secondary signification) atau dalam tingkat konotasi. Pada tingkat inilah warisan pemikiran Saussure diperluas oleh Barthes dengan membongkar praktik sentimenpada tingkat konotasi tanda. Konotasi oleh Barthes malah mensignifikasikan entitas hal yang disebutkannya sebagai mitos. Yang perlu dimengertiialah bahwa mitos ini memiliki konotasi pada ideologi tertentu.

Pada penelitian berikut semiotika dijalankan dengan mengkaji tanda-tanda yang ada dalam iklan Iklan Djarum Super Edisi Paolo Maldini. Iklan Djarum Super Edisi Paolo Maldini yang diteliti disituasikan seperti teks yang menggambarkan rajutan dari berbagai tanda. Tanda-tanda yang terlihat baik dalam bentuk gambar, tulisan ataupun suara diambil dari shootsertascene yang terdapat pada iklan Djarum Super Edisi Paolo Maldini. Pada bagian hasil penelitian, peneliti mengemukakan pemaknaan secara denotatif dan konotatif, yang akhirnya dilanjutkan menggunakan pembahasan yang menguraikan temuan-temuan penelitian oleh intertekstualitas dengan berbagai macam teori yang substansial.

\section{HASIL DAN PEMBAHASAN}

HASIL

Pada bagian ini, kami menguraikan hasil dan pembahasan dari iklan Djarum Super Versi Paolo Maldini tahun 2012 yang berdurasi 1 menit. Analisisnya menggunakan tiga tahapan semiotika Roland Barthes, yaitu denotasi, konotasi serta mitos.

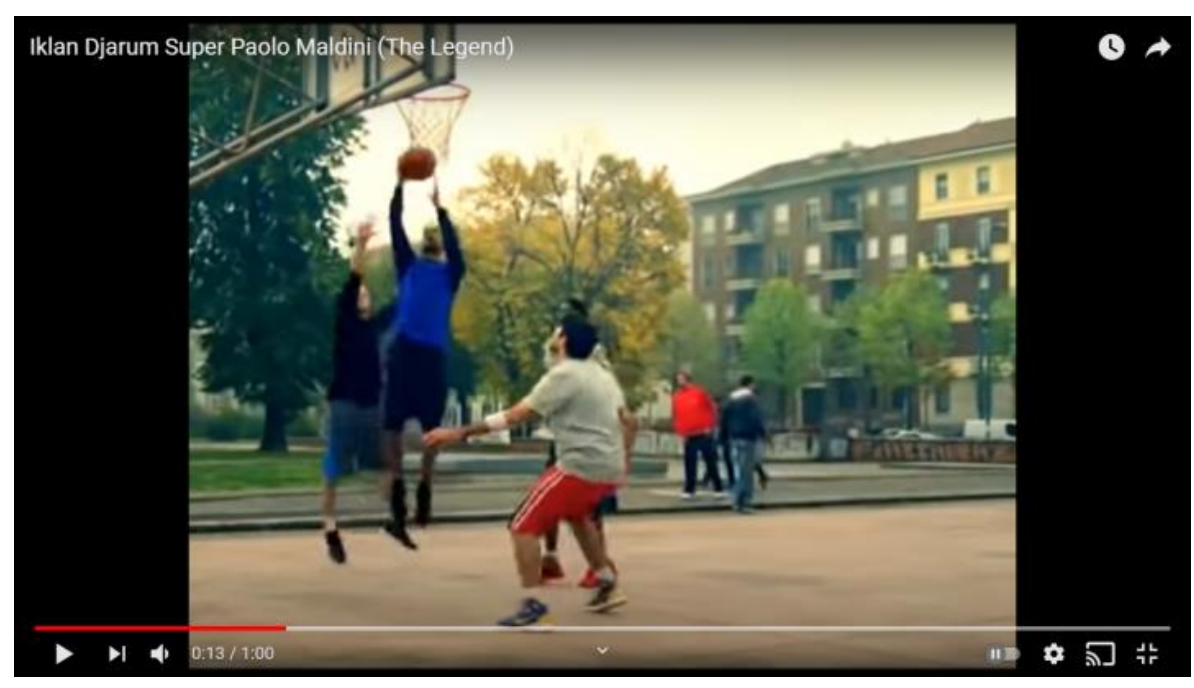

Gambar 1. Bagian 1 Iklan Djarum Super Versi Paolo Maldini

Makna Denotasi: Petanda yang muncul pada Gambar 1 adalah pria berbaju biru (Tony Parker) memperlihatkan keahliannya dalam bermain basket pada sebuah lapangan basket. Tony Parker terlihat menggunakan baju bermerek nike. Tanda yang muncul jelas pada gambar 1 ialah mempertontonkan bahwa Tony Parker hebat dalam bermain basket.

Makna Konotasi: Pemain basket harus pakai pakaian bermerek seperti yang terlihat pada gambar 1 . Karena pakaian bermerek merupakan salah satu faktor penunjang penampilan dalam berolahraga. Pemain profesioanl identik dengan pakaian bermerek karena mempunyai kesan bahwa pakaian bermerek menambah skill dilapangan. 
Mitos: Mitos yang terdapat pada gambar diatas ialah bahwa seseorang yang mengenakan pakaian bermerek pada saat olahraga dalam hal ini bermain basket memiliki anggapan dia hebat dalam hal tersebut. Sehingga memiliki anggapan bahwa pakaian bermerek memiliki dampak dalam permainan.

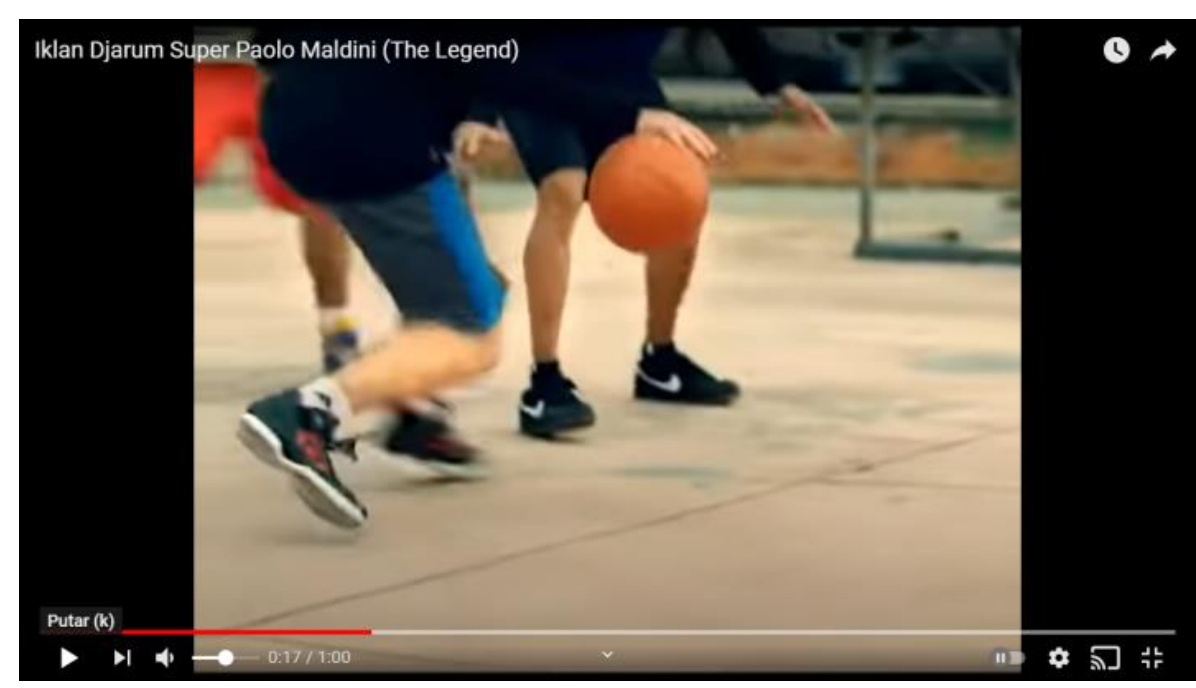

Gambar 2. Bagian 2 Iklan Djarum Super Versi Paolo Maldini

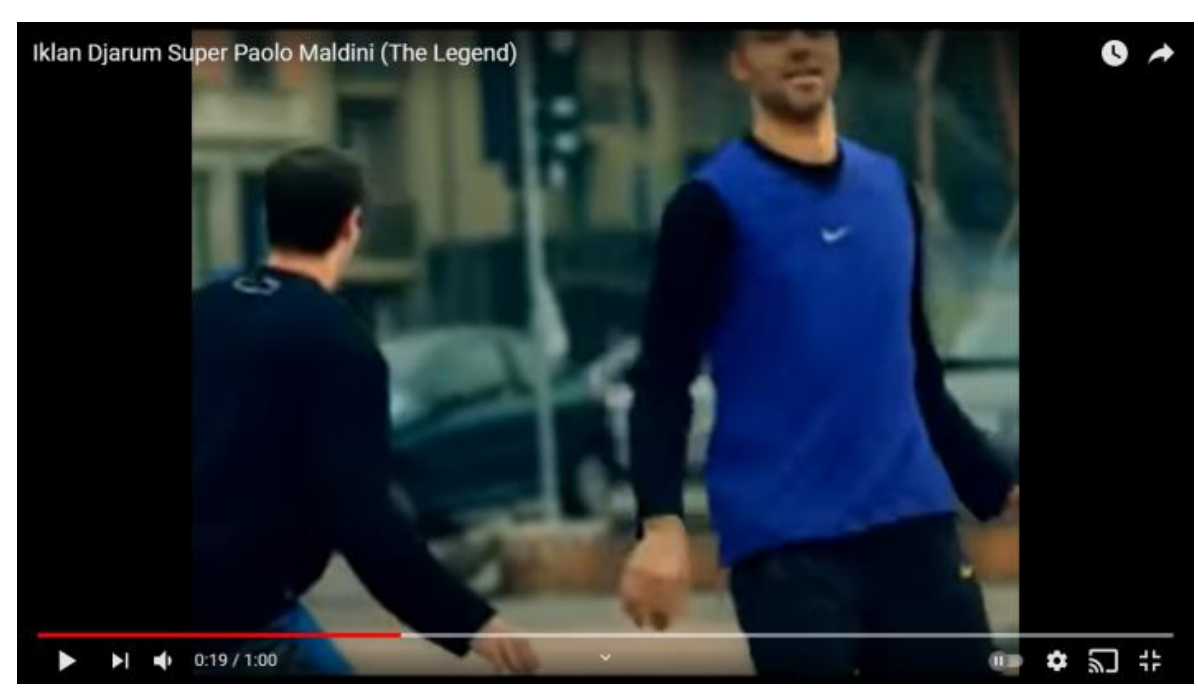

Gambar 3. Bagian 3 Iklan Djarum Super Versi Paolo Maldini

Makna Denotasi: Pada gambar 2 memperlihatkan dua orang pria sedang bermian basket, dan seperti yang terlihat pada gambar diatas bahwa dua-duanya memakai sepatu bermerek yakni nike dan adidas. Dan pada gambar 3 menampilkan bahwa orang dengan sepatu Nike berhasil mem-block dari orang bersepatu adidas

Makna Konotasi: Seseorang yang bermain basket harus mengenakan sepatu bermerek. Seperti yang terlihat pada gambar 2. Serta orang yang mengenakan sepatu dengan sepatu Nike lebih hebat daripada orang dengan sepatu Adidas. Sepatu Nike dan Adidas memiliki konotasi sebagai sepatu yang bermerek yang dipakai pemain sepakbola papan atas.

Mitos: Mitos yang terdapat pada gambar 2 dan 3 ialah orang mengenakan sepatu Nike saat berolahraga lebih hebat bila dibandingkan orang yang berolahraga dengan sepatu Adidas. Sehingga muncul mitos bahwa sepatu Nike lebih baik dari sepatu Adidas, namun keduanya adalah simbol dari sepatu olahraga kelas atas. 


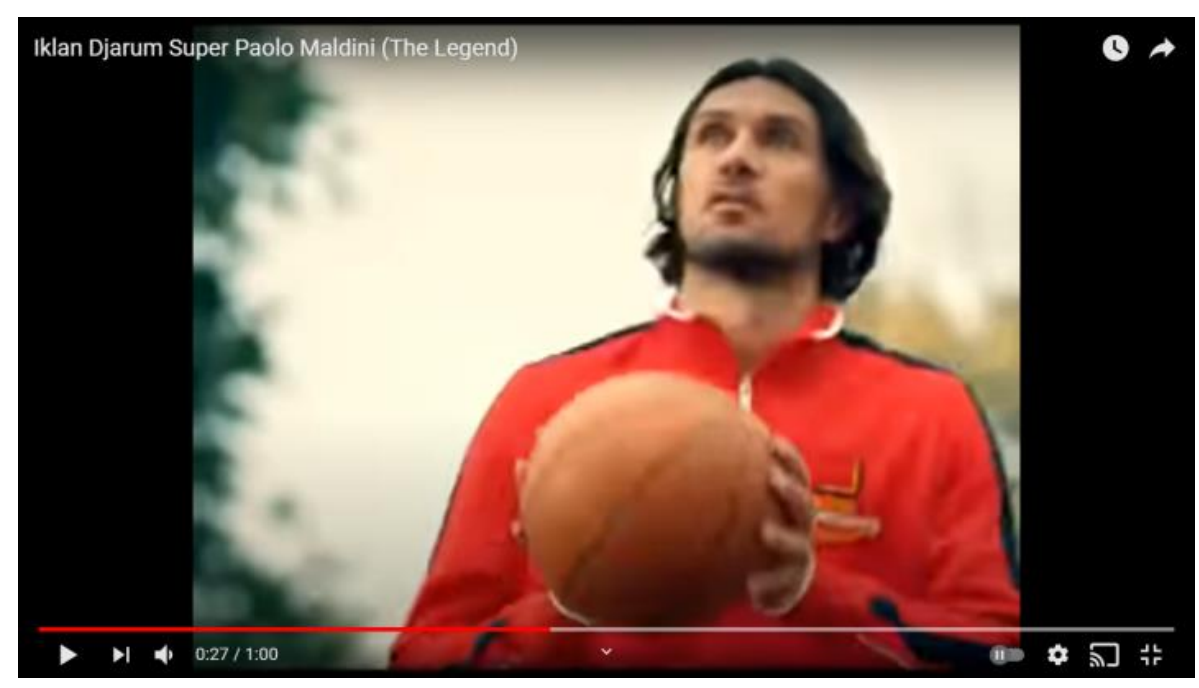

Gambar 4. Bagian 4 Iklan Djarum Super Versi Paolo Maldini

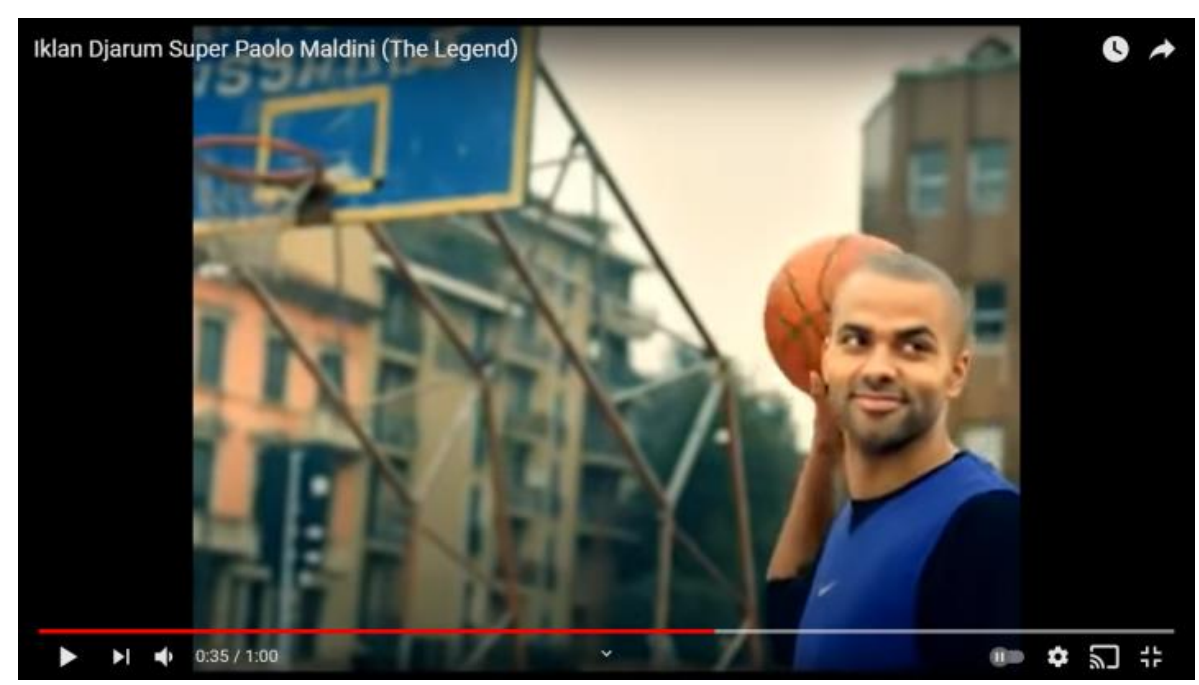

Gambar 5. Bagian 5 Iklan Djarum Super Versi Paolo Maldini

Makna Denotasi: Pada gambar 4 menampilkan Paolo Maldini tidak mampu memasukan bola basket dengan tangannya yang kemudian ditertawakan. Lalu pada gambar 5 Tony Parker berhasil memasukan bola dengan mudah dengan tanpa melihat kearah ring basket.

Makna Konotasi: Makna Konotasi yang terdapat pada adegan tersebut ialah pemain basket yang handal haruslah menggunakan baju bermerek. Yang artinya bahwa orang tidak mengenakan pakaian bermerek tidak lebh baik daripada mereka yang memaiaki pakaian bermerek

Mitos: Baju dan sepatu basket bermerek tidak mempengaruhi pemain saat memasukkan bola ke ring sebab kemampuan tersebut dapat didapat dengan latihan, bukan dikarenakan perlengkapan seperti baju dan sepatu basket yang dikenakan.

\section{PEMBAHASAN}

Representasi budaya konsumen telah mempengaruhi cara-cara masyarakat mengekspresikan estetika dan gaya hidup. Konsep tentang representasi sudah dijabarkan pada bagian awal jurnal ini. Menurut Stuart Hall, konsep representasi merupakan produksi makna konsep pada pikiran kita lewat bahasa, itu merupakan relasi antara konsep dan bahasa yang kemungkinan kita untuk merujuk ke dunia sungguhan mengenai objek, orang atau peristiwa, atau bahkan dunia imajiner benda fiksi, orang, serta peristiwa. 
Representasi juga menjadi bagian vital dari proses dimana makna diproduksi dan terjadi pertukaran antara anggota budaya. Hal ini melibatkan penggunaan bahasa, tanda-tanda, serta visual yang mewakili atau mewakili sesuatu. Selain itu representasi juga berarti mengaplikasikan bahasa untuk menyuarakan sesuatu makna tentang, atau untuk mewakili dunia secara bermakna kepada orang lain (Hall, 1997)

Hal yang telah disampaikan oleh Stuart Hall mengenai representasi, akhirnya menjadikan pemaknaan terhadap budaya konsumen identik dengan penggunaan bahasa, tanda-tanda, serta visual yang mewakili atau mewakili sesuatu. Sesuai dengan konsep representasi yang diartikan sebagai pengaplikasian bahasa untuk menyuarakan sesuatu makna tentang, budaya konsumen menjadi simbol dan pakaian bermerek sebagai objek yang dimaksud dalam pembahasan ini

Media memiliki peran yang cukup besar pada menyebarnya representasi buday konsumen. Media dalam hal ini memiliki kaitan dengan iklan, dimana iklan menjadi media dalam memberikan penggambaran budaya konsumen. Iklan rokok Djarum Super edisi Paolo Maldini menjadi bahan dari penelitian ini sangat cocok dengan pembahasan mengenai budaya konsumen, karena pada iklan tersebut terdapat beberapa makna yang sesuai dengan metode penelitian semiotika menurut Roland Barthes, yaitu denotasi, konotasi serta mitos.

Hasil dari penelitian ini menunjukkan bahwa seseorang harus mengenakan pakaian bermerek seperti yang terdapat pada iklan Djarum Super. Selain penggunaan pakaian bermerek, sepatu bermerek juga tak ketinggalan untuk dikenakan supaya menambah kesan hebat atau jago pada saat bermain basket. Melihat gambaran yang diperlihatkan pada iklan tersebut, membuat masyarakat secaa umum berbondongbondong membelanjakan uangnya untuk membeli pakaian bermerek untuk dikenakan saat berolahraga.

Seperti yang diutarakan (Hackley, 2014) bagi masyarakat secara umum barang bermerek membawa janji kualitas dan nilai. Namun secara simbolis berarti merek tersebut mungkin memiliki teman, kenalan dan orang asing tidak bisa didiskon sebagai faktor daya tariknya. Misalnya, item sederhana dari pakaian seperti kemeja akan laku dalam jumlah yang jauh lebih banyak jika memang demikian dihiasi dengan logo yang memberikan makna simbolis di atasnya barang. Mengenakan kemeja bermerek Tommy Hilfiger dikatakan branding prestige pada pemakainya karena nilai-nilai kemakmuran dan hak istimewa sosial yang diwakili oleh merek. Hal ini menunjukan bahwa pakaian dengan merek logo terkenal mampu memberikan makna simbolis, seperti yang terlihat pada iklan Djarum Super edisi Paolo maldini bahwa orang yang mengenakan sepatu berlogo swosh nike memberikan hak istimewa sosial yang terwakilkan oleh merek.

Penelitian sebelumnya yang dinyatakan oleh Nurist (2010), menyatakan bahwa perkembangan budaya konsumen sudah berpengaruh terhadap cara masyarakat memanifestasikan keindahan serta gaya hidup. Pada masyarakat konsumen, terjadi fluktuasi mendasar berkaitan dengan cara orang memanifestasikan diri dalam gaya hidupnya. Gaya hidup merupakan salah satu konstruksi budaya konsumen. Karena pada dasarnya, gaya hidup seseorang hanya dilihat dari sesuatu yang mereka konsumsi, baik konsumsi barang maupun jasa. Secara harfiah, konsumsi berarti pemakaian produk untuk memenuhi kebutuhan dan hasrat. Konsumsi tidak cuma mencakup kegiatan pembelian sejumlah barang, misalnya televisi dan mobil tetapi juga mengkonsumsi jasa, seperti pergi liburan serta beragam pengalaman sosial.

Hampir serupa dengan apa yang dijabarkan oleh Nurist (2010). Temuan pada penelitian ini pun mengindikasikan bahwa perkembangan budaya konsumen telah berdampak terhadap cara masyarakat mengekspresikan diri dalam gaya hidupnya. Sama seperti apa yang dijabarkan oleh peneliti sebelumnya bahwa gaya hidup merupakan salah satu konstruksi budaya konsumen yang hanya bisa dilihat dari apa yang mereka konsumsi, baik konsumsi barang maupun konsumsi jasa. Dengan penggunaan pakaian bermerek saat berolahraga mengindikasikan bahwa orang tersebut sedang mengekspresikan diri dalam gaya hidupnya, hal ini bisa terlihat dari apa yang konsumen pakai. 
Hal tentang budaya konsumen juga pernah diutarkan oleh (Rafa'al, 2017), menurutnya belanja bukan lagi hanya kegiatan untuk pemenuhan kebutuhan pribadi. Jika pada mulanya belanja adalah kegiatan awal untuk mengonsumsi barang, namun sekarang belanja adalah kegiatan mengonsumsi itu sendiri. Belanja bukan hanya sekadar menjadi instrumen untuk mendapatkan barang yang diinginkan, belanja menjadi kegiatan yang pokok ketika konsumsi sudah menjadi gaya hidup. Saat ini orang menikmati kegiatan belanja itu sendiri. Di sisi lain, manusia tidak cuma membeli barang yang dibutuhkan, namun juga merek. Merek barang tersebut memunculkan kebanggaan diri. Membeli barang dengan merek yang sudah ternama memunculkan perasaan diri "lebih" dalam diri penggunanya. Dengan belanja, konsumen tidak hanya mengonsumsi nilai, bahan atau nilai kegunaan dari barang yang dibelinya, namun juga apa yang ditandakan oleh barang tersebut.

Bila dibandingkan dengan hasil penelitian dari Mubaddilah Rafa'al, hasil penelitian yang kami lakukan juga kurang lebih sama. Iklan Djarum Super edisi Paolo Maldini yang menjadi bahan dari penelitian ini juga mengamini bahwa kegiatan belanja bukan lagi sebuah kegiatan pemenuhan kebutuhan tetapi sudah menjadi instrumen untuk mendapat barang yang diinginkan. Manusia tidak hanya membeli barang yang dibutuhkan namun juga merek. Seseorang yang menggunakan barang bermerek (Nike) membeli sepatu untuk aktivitasnya bukan hanya melihat nilai kegunaan dari barang tersebut tetapi juga apa yang ditandakan oleh sepatu tersebut.

Berkaitan dengan iklan, (Devi, 2014) Iklan merupakan sebuah cara dalam mempopulerkan hasil karya berupa suatu produk kepada masyarakat. Boleh dibilang juga ini sebuah cara mensosialisasikan supaya masyarakat tahu keberadaan produk tersebut, iklan juga memerlukan suatu media baik media massa maupun media elektronik. Keberadaan iklan amat menjadi penanggungjawab mengenai budaya konsumtif yang merupakan hasil pencitraan atau penggambaran yang dibuat oleh pengiklan. Kenyataannya perubahan pola hidup masyarakat telah berubah seiring perkembangan teknologi, salah satunya lewat media televisi yang sangat miris saat ini.

Serupa dengan hasil dari penelitian yang dilakukan oleh Silvia Devi, penelitian ini menemukan hasil bahwa keberadaan iklan sangat berpengaruh terhdap budaya konsumen dalam hal ini budaya konsumtif, budaya konsumtif ini muncul akibat dari pencitraan yang dibuat pengiklan. Seperti pada iklan Djarum Super edisi Paolo Maldini yang menampilkan sekelompok orang dengan pakaian bermerek sedang bermian basket pada sebuah lapanagan basket. Dengan adanya pakaian bermerek pada iklan ini merubah pola hidup masyarakat, terlebih lagi iklan ditayangkan secara masif pada masanya dimedia televisi (Devi, 2014).

\section{KESIMPULAN}

Kesimpulan yang didapatkan dari paper ini ialah iklan Djarum Soccer edisi Paolo Maldini memiliki makna denotasi, konotasi dan mitos pada setiap adegan oleh tokoh atau pemeran iklan. Tidak hanya melalui adegannya, akan tetapi penampilan pemeran juga memiliki makna bagi iklan tersebut yang memiliki simbol tersendiri saat menyampaikan pesan terhadap masyarakat saat melihat iklan tersebut. Mitos dari iklan ini adalah bahwa menjadi olahragawan terkenal identik dengan pemakaian fashion yang memiliki merek terkenal. Keberadaan olahraga tidak lepas dari budaya konsumen, yaitu penggunaan merek ternama, seperti Nike dan Adidas. Mitos ini menunjukan adanya budaya konsumen dalam iklan.

\section{PERSANTUNAN}

Terima kasih kepada Dr, Fajar Junaedi yang telah membimbing proses riset dalam mata kuliah Kajian Kritis Iklan di program studi Ilmu Komunikasi Universitas Muhammadiyah Yogyakarta selama satu semester genap tahun akademik 2020/2021 yang menghasilkan iuran berupa arikel ini. 


\section{REFERENSI}

Armstrong, J. S. (2010). Persuasive advertising: Evidence-based principles. Palgrave Macmillan.

Berger, A. A. (2010). The objects of affection: semiotics and consumer culture. In Choice Reviews Online (Vol. 48, Issue 07). https://doi.org/10.5860/choice.48-3685

Bradley, C., \& Cracknell, A. (2009). The mathematical theory of symmetry in solids: representation theory for point groups and space groups. Oxford University Press.

Devi, S. (2014). Budaya Konsumen Masyarakat Modern. 68-70.

Dittmar, H. (2007). Consumer culture, identity and well-being: The search for the'good life'and the'body perfect'. Psychology Press.

Hackley, C. (2014). Advertising and promotion. Sage.

Hall, S. (1997). REPRESENTATION: CULTURAL REPRESENTATIONS AND SIGNIFYING PRACTICES. In Angewandte Chemie International Edition, 6(11), 951-952.

Hanum, Z., \& Hidayat, S. (2017). Faktor - faktor yang mempengaruhi perilaku konsumen dalam keputusan pembelian sepatu merek Nike di kota medan. Jurnal Bisnis Administras, 06(01), 37-43.

Hartley, J. (2003). A short history of cultural studies. In A Short History of Cultural Studies. https://doi.org/10.4135/9781446216934

Laughey, D. (2007). Key themes in media theory. In Key themes in media theory.

Nurist, S. (2010). Posmodernisme dan budaya konsumen. In Posmodernisme dan Budaya Konsumen.

Rafa'al, M. (2017). Identitas Gaya Hidup dan Budaya Konsumen dalam Mengkonsumsi Brand The Executive. Jurnal Komunikasi Profesional, 1(1), 49-57. https://doi.org/10.25139/jkp.v1i1.173

Rosida, I. (2018). Tubuh Perempuan Dalam Budaya Konsumen: Antara Kesenangan Diri, Status Sosial, Dan Nilai Patriarki. Jurnal Antropologi: Isu-Isu Sosial Budaya, 20(1), 85. https://doi.org/10.25077/jantro.v20.n1.p85-101.2018

Siringoringo, H. (2004). Peran Bauran Pemasaran Terhadap Perilaku Pembelian Konsumen. Peran Bauran Pemasaran Terhadap Perilaku Pembelian Konsumen, 100, 125-137. 